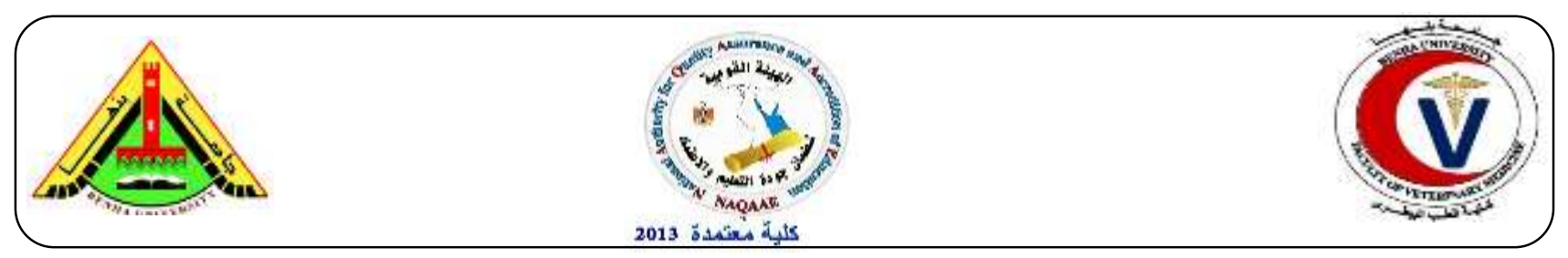

\title{
Antioxidant and hepatoprotective effects of pumpkin seed oil in CCl4-intoxicated rats
}

\author{
Manal Hamdy Elmeligy, Ayman Samir Farid, Khalid Mostafa Fararh \\ Department of Clinical Pathology, Faculty of Veterinary Medicine, Benha University
}

\section{A B S T R A C T}

This study aimed to investigate the hepatoprotective and antioxidant effect of pumpkin seed oil (PSO) against Carbon tetrachloride $\left(\mathrm{CCl}_{4}\right)$ induced hepatotoxicity. For this purpose, 40 male albino rats were divided into four groups. Group (1) was maintained as normal control group, were given the vehicle. Group (2) was administered with pumpkin seed oil alone at a dose of $300 \mathrm{mg} / \mathrm{kg}$. b.w /day orally. Group (3) received $\mathrm{CCl}_{4}$ alone at a dose of $2.5 \mathrm{ml} / \mathrm{kg} \mathrm{b.w}$. (30\%) $\mathrm{CCl}_{4} /$ corn oil intraperitoneally after $2 \& 3$ weeks of the experiment. Group (4) was given both $300 \mathrm{mg} / \mathrm{kg}$. b.w./day pumpkin seed oil for 3 weeks and $2.5 \mathrm{ml} \mathrm{CCl} 4$ as in (group 3). Fourty eight hours after the $2^{\text {nd }} \mathrm{CCl}_{4}$ injection blood samples and liver tissues were collected for biochemical, histopathological and immunohistochemical examinations. In $\mathrm{CCl}_{4}$ group, Alanine aminotransferase (ALT), Aspartate aminotransferase AST and T. bilirubin in serum significantly increased in serum while Total protein and albumin significantly reduced. Hepatic Malondialdehyde MDA levels increased and antioxidant enzymes superoxide dismutase \&catalase (SOD \& CAT) were decreased. Group (4) revealed significant decrease of the hepatic damage, ALT, AST \& T. bilirubin while T. protein and albumin significantly increased. Hepatic MDA levels decreased and the efficiency of antioxidant enzymes (SOD \& CAT) was improved when compared to $\mathrm{CCl}_{4}$ group. The liver from $\mathrm{CCl}_{4}$-induced damage. Moreover, immunohistochemistry staining demonstrated that pretreatment with PSO significantly inhibited the elevation of iNOS in $\mathrm{CCl}_{4}$-treated rats. It is concluded that pumpkin seed oil has hepatoprotective and antioxidant effects.

Keywords: Pumpkin seed oil, hepatoprotective, antioxidant, $\mathrm{CCl}_{4}$, iNOS.

Received: 25 June 2019, Accepted: 23 August 2019 (http://www.bvmj.bu.edu.eg)

(BVMJ-36(2): 77-89, 2019)

\section{INTRODUCTION}

Liver plays an important role in filtering and clearing blood received from digestive tract prior to passing it to other body tissues and organs. Also, it is transforming, detoxifying, and accumulating metabolites and in mediating drug transformations and metabolism. So, the liver is highly susceptible to damage from different toxins, viruses, and reactive oxygen and nitrogen species (Lu et al., 2018). This damage of the liver is often associated with liver metabolic and synthetic dysfunctions which can result in many disorders, such as the transient elevation of levels of hepatic enzymes, hepatic fibrosis, cirrhosis of the liver, and even hepatocellular carcinoma (Srivastava, Shivanandappa, 2010). Hepatic 
diseases are usual in large animals, diseases that frequently result in hepatic failure in horses include pyrrolizidine alkaloid toxicosis, hepatic lipidosis, suppurative cholangitis or cholangiohepatitis, cholelithiasis, and chronic active hepatitis. Obstructive disorders, aflatoxicosis, leukoencephalomalacia, pancreatic disease, hepatic abscess, and perinatal herpes virus 1 infections sporadically result in hepatic failure. In ruminant animals, hepatobiliary disease is related by hepatic lipidosis, hepatic abscesses, endotoxemia pyrrolizidine alkaloid and other plant toxicosis, certain clostridial diseases, liver flukes, mycotoxicosis and mineral toxicosis or deficiency. Vitamin E or selenium deficiency, aflatoxicosis, ascarid migration bacterial hepatitis, and ingestion of toxic substances are related by hepatic damage (Davoudi et al., 2013).

Carbon tetrachloride $\left(\mathrm{CCl}_{4}\right)$ has been widely used as hepatotoxins models in the experimental study of liver disease. Carbon tetrachloride induces hepato-toxicity by metabolic activation. It is metabolically activated by the cytochrome $\mathrm{P} 450$ in the endoplasmic reticulum to form a trichloromethyl free radical $\left(\mathrm{CCl}_{3}\right)$ which induces oxidative stress leading to liver damage (Sheweita et al., 2001). Oxidative stress is the result of the imbalance between the production of free radicals and their scavenging by the antioxidant defense mechanism (Lum and Roebuck, 2001). Some plants through their antioxidant activities (Fadhel and Amran, 2002), inhibition of CYP2E1, activation of NFKB and inhibition of inflammatory cytokines (Saba, et al., 2010), having protective effect against the hepatotoxicity induced by $\mathrm{CCl}_{4}$. Herbal drugs used as alternative healthcare options that are more effective and safer. It plays a role in management of various liver diseases most of them accelerate the natural healing processes of the liver. Herbal drugs are rich in antioxidants, especially in those prevent the dangerous effects of free radicals in the human body (Osadebe et al., 2012).

Pumpkin seeds (cucurbita pepo l.) are plants that have been used as functional food or medicine. They are a natural source rich of unsaturated fatty acids, essential fatty acidomega6, omega9, phytosterols and antioxidants such as carotenoids, vitamin A and vitamin E (Murkovic et al., 1996). Also those contained tocopheroles, fibers, proteins, phytosterols and trace elements such as zinc, selenium, sodium, calcium, magnesium, potassium and phosphorus (Eraslan et al., 2013). Pumpkin seed oil exhibit several therapeutic activities like anti-atherogenic and hepatoprotective (Makni et al., 2008), antidiabetic (Bharti et al., 2013), wound healing (Bardaa et al., 2016), anti-inflammatory (Oliveira et al., 2013), antibacterial (Adeel et al., 2013), antihypertensive (AL-Zuhair et al., 2000), antiartheritis (Fahim et al., 1995), antidepressant (George and Nazni, 2012), antihyperlipidimic (Gossell-Williams et al., 2011) and anticancer (Medjakovic et al., 2016).

Therefore, this study aimed to investigate the hepatoprotective and antioxidant effect of pumpkin seed oil (PSO) against Carbon tetra chloride $\left(\mathrm{CCl}_{4}\right)$ induced hepatotoxicity.

\section{Materials and methods}

\subsection{Experimental Animals:}

Forty male albino rats weighting about 150170 grams body weight were obtained from the Laboratory Animals Research Center, Faculty of Veterinary Medicine, Benha University, Egypt. Rats were housed in separate metal cages and maintained on a standard balanced ration with free access to tap water. They were acclimatized for 10 days before starting the experiment.

\subsection{Chemicals used for experiment:}


Carbon tetra chloride $\left(\mathrm{CCL}_{4}\right)$ obtained from Alalamya Company, Egypt.

\subsection{Plant material:}

Healthy fruits of (fluted pumpkin) were obtained from local markets. The plant samples were identified and authenticated by the botanist, Faculty of Agriculture, Benha University.

\section{Extract preparation:}

Fluted pumpkin seeds were decocted with a lancet and the seeds dried in the oven in the laboratory at $30{ }^{\circ} \mathrm{C}$ for 48 hours. The seeds were grinded to a fine powder using electric blender and preserved for extraction of the oil samples. The oil was extracted using petroleum ether in continuous extraction with a soxhlet reflux apparatus as described in Reinhold, (1992) and Ojiako and Nwanjo, (2006). The extraction continues till the petroleum ether completely evaporated using a rotatory flask evaporator. The oil left after evaporation of the petroleum ether was used in our experiments.

\subsection{Experimental design:}

In our study, 40 male albino rats were acclimatized to the laboratory conditions for 10 days, and then divided into 4 groups (10/group) Normal control rats (group 1) served as control and orally given the equivalent volume of the vehicle (corn oil) daily for 3 weeks. Pumpkin administrated rats (group 2) were given $300 \mathrm{mg} / \mathrm{kg}$ b.w. Pumpkin seed oil (PSO) for 3 weeks according to Aghaei et al., (2014) with some modifications. $\mathrm{CCL}_{4}$ injected rats (group3) were injected intraperitoneally with $2.5 \mathrm{ml} / \mathrm{kg}$ b.w., $30 \%$ $\mathrm{CCL}_{4}$ /corn oil after 2 weeks and after 3 weeks according to Mahli et al., (2015) with some modifications. $\mathrm{CCL}_{4}$ injected rats protected with pumpkin (group 4) were administered pumpkin seed oil $300 \mathrm{mg} / \mathrm{kg}$ b.w orally/day for 3 weeks and injected intraperitoneally with $2.5 \mathrm{ml} / \mathrm{kg}$ b.w. $30 \% \mathrm{CCL}_{4} /$ corn oil after 2 weeks and after 3 weeks.

\subsection{Sampling:}

A-Blood samples: were collected after $24 \mathrm{hrs}$ of CCL4 injection (after 3 weeks) by retroorbital methods from each group then sacrificing.

$3 \mathrm{ml}$ Blood samples were collected in gel tubes for separation of serum to be used in estimation of biochemical parameters including ALT, AST, T. protein, Albumin and T. bilirubin. The collected blood samples were allowed to clot then centrifuged at 3000 r.p.m for 15 minutes for obtaining serum samples. Sera were kept in deep freeze at $-20^{\circ} \mathrm{C}$ till the time of examination.

\section{$B$ - Liver tissue specimens:}

Liver specimens were collected from all groups of rats 3 weeks quickly after sacrificing and divided into 2 parts: First part used for estimation of the concentration of malondialdehyde (MDA) as a lipid peroxidation product and antioxidant enzymes activities including super oxide dismutase (SOD) and catalase (CAT). Second part used for histopathological examination and immunohistochemistry examination of inducible nitric oxide synthetase (iNOS).

\subsection{Biochemical parameters measurement:}

Serum Alanine aminotransferase (ALT) and Aspartate aminotransferase (AST) activities were determined according to the method of Burtis and Bruns, (2014). Serum total protein concentration was determined by the reaction described by Henry et al., (1974). Albumin was determined by colorimetric method described by Young (1995). Total bilirubin was determined by colorimetric method according to Burits et al., (2012).

\subsection{Hepatic lipid peroxidation and antioxidant enzymes:}

Malondialdehyde (MDA), Superoxide Dismutase (SOD) and Catalase (CAT) were determined by ELIZA technique.

2.8. Histopathological examinations:

Medium portions of liver drawn from tested and control rats were fixed in $10 \%$ formalin, 
processed by standard procedure for paraffin embedding. Then $4 \mu \mathrm{m}$ serial sections were cut and stained with hematoxylin-eosin (Banchroft and Gamble, 2008).

2.9. Immunohistochemistry study of inducible nitric oxide synthetase (iNOS):

The immunohistochemical procedures were done according to (Abdo et al, 2014). The serial sections were dewaxed, hydrated, and immersed in antigen retrieval (EDTA solution, $\mathrm{pH}$ 8). They were then treated with hydrogen peroxide $0.3 \%$ and protein block, followed by incubation with mouse monoclonal anti-iNOS (1:200 dilution). The slides were rinsed three times with PBS, incubated with anti-mouse IgG secondary antibodies for 30 minutes at room temperature, visualized with diaminobenzidine commercial kits. Finally, counterstained with Mayer's hematoxylin. As a negative control procedure, the primary antibody was replaced by normal mouse serum. The labelling index of iNOS were expressed as the percentage of positive cells per total 1000 counted cells in about 6 to 8 high power fields.

\subsection{Statistical analysis:}

Data of this study were statistically evaluated for the mean and standard error (S.E). All differences between groups were determined by one-way ANOVA. Differences between individual groups were estimated by Fisher's protected least-significant difference (LSD) test as described by Spring et al., (2000), if the one-way ANOVA was significant. $\mathrm{P}<0.05$ was considered statistically significant.

\section{RESULTS}

After 3 weeks the changes in hepatic functions including ALT, AST, T. protein, Albumin, globulin and T. bilirubin are illustrated in table (1). Regarding to Pumpkin seed oil administered normal rats in group 2 when compared to the normal control, it showed non-significant changes in ALT, AST, T. bilirubin, T. protein, Albumin and Globulin.
Rats injected with $\mathrm{CCL}_{4}$ in group3 when compared to the normal control rats revealed significant increase in ALT, AST and T. bilirubin, while showed significant decrease in T. protein, Albumin and Globulin. On the other hand, data of $\mathrm{CCL}_{4}$ injected rats protected with pumpkin in group 4 represented significant decrease in ALT \& AST activities, T. bilirubin and significant increase of $\mathrm{T}$. protein, albumin and globulin compared to $\mathrm{CCL}_{4}$ injected rats in group3.

Table (2) illustrates the changes in MDA, SOD and CAT after 3 weeks. Concerning to pumpkin seed oil administered normal rats in group (2), when compared with the normal control rats in group1 showed non- significant changes in MDA, SOD and CAT. $\mathrm{CCL}_{4}$ injected rats in group (3) showed significant increase in MDA, while showed significant decrease in the activities SOD and CAT compared to the normal control rats. On the other hand, $\mathrm{CCL}_{4}$ injected rats protected with pumpkin compared to $\mathrm{CCL}_{4}$ injected rats in group 3 showed significant decreases in MDA, while showed significant increase in SOD and CAT activities.

Histopathological finding in the liver tissue after 3 weeks of the experiment Rats kept as control (group 1) showed no histopathological alteration (Fig.1.A). Rats administered pumpkin seed oil only (group 2) showing no histopathological alteration and normal hepatocytes arranged in cords around the central vein as recorded in (Fig.1. B). Rats injected with $\mathrm{CCL}_{4}$ (group 3) showed extensive coagulative necrosis associated with congestion of the portal blood vessels with periportal attempts of hepatic proliferation and marked fibroblastic cells proliferation (Fig.1. C). $\mathrm{CCl}_{4}$ protected rats with pumpkin (group 4) showed limited periportal fibrosis lesion and marked decrease of both hepatic vacuolation and necrosis (Fig.1. D). 
Immunohistochemistry finding: The immunopathological reaction in hepatic tissue was examined through investigation of Inducible nitric oxide syntheses (INOS) expression and apoptosis in the liver. Group of rats kept as control group (group 1) showed no immunopathological reaction observed in the liver and negative expression of INOS within the normal hepatocytes after 3 weeks of the experiment (Fig.2.E). Rats administered pumpkin seed oil only (group 2): showed mild expression of INOS within hepatic tissues (Fig.2.F). Rats injected with $\mathrm{CCL}_{4}$ (group 3): showed marked periportal expression of INOS mostly related with the fibrotic areas (Fig.2.G). Group of $\mathrm{CCl} 4$ injected rats protected with pumpkin (group4): Showed mild immunopathological reaction in hepatic tissue. INOS expression was significantly and marked decreased within the affected periportal hepatocytes (Fig.2.H).

Table1: Changes in serum biochemical parameters 3 weeks after starting the experiment in different experimental groups.

\begin{tabular}{|c|c|c|c|c|c|c|}
\hline \multirow[t]{2}{*}{ Groups } & \multicolumn{6}{|c|}{ Parameters } \\
\hline & $(\mathrm{U} / \mathrm{L})$ & $\begin{array}{l}\mathrm{AST} \\
(\mathrm{U} / \mathrm{L})\end{array}$ & $\begin{array}{l}\mathrm{T} . \text { protein } \\
(\mathrm{g} / \mathrm{dl})\end{array}$ & $\begin{array}{l}\text { Albumin } \\
(\mathrm{g} / \mathrm{dl})\end{array}$ & $\begin{array}{l}\text { Globulin } \\
(\mathrm{g} / \mathrm{dl})\end{array}$ & $\begin{array}{l}\mathrm{T} . \\
\text { bilirubin } \\
(\mathrm{mg} / \mathrm{dl})\end{array}$ \\
\hline $\begin{array}{l}\text { (Control) } \\
\text { Group } 1\end{array}$ & $54.80 \pm 2.96^{\mathrm{c}}$ & $98.60 \pm 10.20^{c}$ & $6.55 \pm 0.06^{\mathrm{ab}}$ & $2.73 \pm 0.05^{\mathrm{a}}$ & $3.83 \pm 0.07^{\mathrm{a}}$ & $0.16 \pm 0.02^{\mathrm{c}}$ \\
\hline $\begin{array}{l}\text { (pumpkin) } \\
\text { Group } 2\end{array}$ & $35.75 \pm 2.81^{\mathrm{c}}$ & $77.50 \pm 8.63^{c}$ & $6.65 \pm 0.16^{\mathrm{a}}$ & $2.78 \pm 0.09^{\mathrm{a}}$ & $3.88 \pm 0.09^{\mathrm{a}}$ & $0.15 \pm 0.03^{\mathrm{c}}$ \\
\hline $\begin{array}{c}(\mathrm{CCl} 4) \\
\text { Group } 3\end{array}$ & $1306.67 \pm 121.97^{\mathrm{a}}$ & $1476.67 \pm 189.06^{\mathrm{a}}$ & $5.5 \pm 0.04^{c}$ & $2.20 \pm 0.09^{\mathrm{b}}$ & $3.30 \pm 0.13^{b}$ & $0.88 \pm 0.12^{\mathrm{a}}$ \\
\hline $\begin{array}{l}(\mathrm{CCl} 4 \\
\text { protected with } \\
\text { pumpkin) }\end{array}$ & \multirow[t]{2}{*}{$226.33 \pm 26.36^{\mathrm{b}}$} & \multirow[t]{2}{*}{$283.67 \pm 31.52^{b}$} & \multirow[t]{2}{*}{$6.35 \pm 0.06^{\mathrm{b}}$} & \multirow[t]{2}{*}{$2.70 \pm 0.07^{\mathrm{a}}$} & \multirow[t]{2}{*}{$3.65 \pm 0.10^{\mathrm{a}}$} & \multirow[t]{2}{*}{$0.50 \pm 0.06^{\mathrm{b}}$} \\
\hline Group 4 & & & & & & \\
\hline
\end{tabular}

Table 2: Changes in MDA, SOD and CAT in liver tissue homogenate 3 weeks after starting the experiment in different experimental groups.

\begin{tabular}{|c|c|c|c|}
\hline & MDA & SOD $\quad \mathrm{u} / \mathrm{mg}$ tissue & CAT \\
\hline (Control) Group1 & $\mathrm{nmol} / \mathrm{mg}$ tissue & $0.30 \pm 0.03 \mathrm{a}$ & ng/mg tissue \\
\hline (pumpkin ) Group 2 & $0.12 \pm 0.03 b$ & $0.30 \pm 0.04 \mathrm{a}$ & $0.31 \pm 0.04 \mathrm{a}$ \\
\hline (CCl4) Group3 & $0.10 \pm 0.01 b$ & $0.10 \pm 0.01 \mathrm{~b}$ & $0.28 \pm 0.03 \mathrm{a}$ \\
\hline $\begin{array}{l}\text { (CCl4 protected with } \\
\text { pumpkin) Group4 }\end{array}$ & $0.45 \pm 0.03 a$ & $0.25 \pm 0.01 \mathrm{a}$ & $0.10 \pm 0.01 b$ \\
\hline
\end{tabular}

Result are expressed as means $\pm \mathrm{SE}$

Different superscript letters ( $a, b$ \& c) within the same column indicate significant differences at $(\mathrm{P}<0.05)$. 


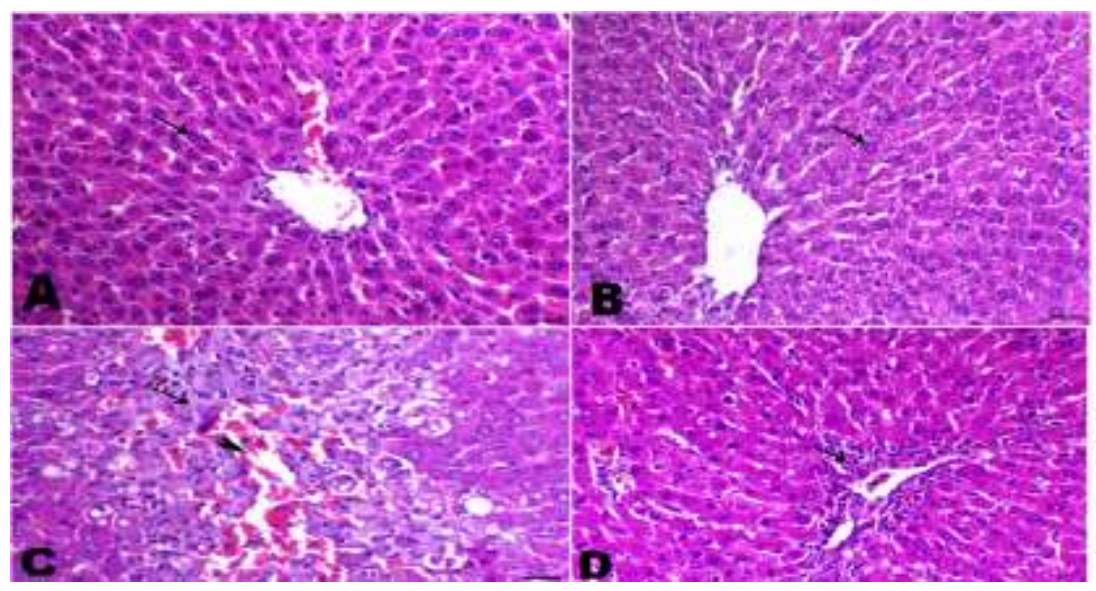

Fig.1. (A): Liver histopathology of normal control rats (Group1) showing normal hepatocytes arranged in cords around the central vein (arrow); (B): Liver histopathology of normal rats treated with pumpkin (group2) showing normal hepatocytes arranged in cords around the central vein (arrow); (C): Liver histopathology of $\mathrm{CC}_{4}$ injected rats (group 3) showing extensive coagulative necrosis (arrow) associated with congestion of the portal blood vessels (arrowhead) with periportal attempts of hepatic proliferation; (D): Liver histopathology of $\mathrm{CCl}_{4}$ injected rats protected with pumpkin (group 4) showing limited periportal fibrosis lesion (arrow), H\&E staining. Original magnification: $X$ 400. (Scale bar $=40 \mu \mathrm{m}$ ).

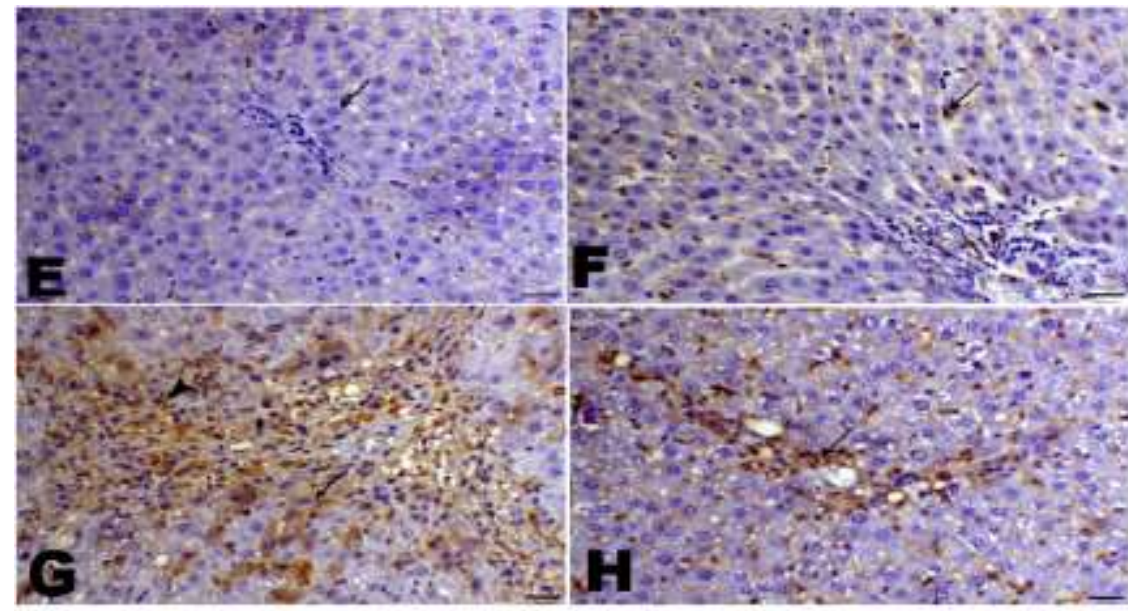

Fig.2.(E): Liver of normal control rats (group1) showing negative expression of iNOS within the normal hepatocytes (arrow); (F): Liver of normal rats treated with pumpkin seed oil (group 2) showing mild expression of iNOS within the hepatic tissues (arrow indicates few sinusoidal cell expressing iNOS; (G): Liver of CCl4 injected rats (group3) showing marked periportal expression of iNOS mostly related with the fibrotic areas (arrow indicates hepatic expression and arrowhead indicates expression within the macrophages); (H): Liver of $\mathrm{CCl} 4$ injected rats protected with pumpkin (group 4) showing marked decrease the expression of iNOS within the hepatocytes (arrow indicates mild periportal iNOS immunostainning), bar $=50 \mu \mathrm{m}$.

\section{DISCUSSION}

Concerning to serum biochemical findings, the present study revealed that administration of $\mathrm{CCl} 4$ to rats caused hepatocellular disturbance indicated by significant increase of ALT, AST and total bilirubin. Our results agree with (Alqarawi et al., 2004). The increased serum levels of ALT and AST caused by cellular leakage, loss of functional integrity of cell membrane and decline of metabolic capacity in liver tissue (Hwang et al., 2007). CCl4 caused 
acute hepatotoxicity characterized by necrosis and apoptosis of the injured hepatocytes and obstruction of the bile duct; cytosolic liver marker enzymes would then leak out from these swollen and necrotic hepatocytes into blood circulation and evidently elevated levels are obtained with impaired liver function (Tochukwu et al., 2018). Serum total protein, albumin and globulin serum level in $\mathrm{CCl}_{4}$ intoxicated rats showed significant reduction when compared to the control rats. This result was in line with Sengottuvelu et al (2007). As the histopathological study of the liver of $\mathrm{CCl} 4$ intoxicated rats revealed Congestion of the portal blood vessels with periportal attempts of hepatic proliferation and marked fibroblastic cells proliferation. Saba et al., (2010) reported that this reduction in serum protein may be due to decrease in the number of intact hepatocytes which in turn, result in decreased hepatic capacity to synthesize protein. Furthermore, this reduction might be due to interaction of $\mathrm{CCl}_{4}$ with protein molecules resulting in impairment of cellular metabolic processes (Chung et al., (2010).

On contrast, Pretreatment of rats with pumpkin seed oil improved liver parameters and decreased hepatocellular disturbance induced by CCl4. Significant decrease was found in hepatic enzymes ALT and AST and Total bilirubin when compared to $\mathrm{CCl} 4$ administrated rats. These results agree with results of Seif, (2014) and Mohamed et al., (2009). This hepatoprotective effect of pumpkin seed oil may be a result of antioxidant activity of phenolics and flavonoids through inhibition of cytochrome P-450 aromatase (Kowalska et al., 1990, Stankovic et al., 2010). Decrease in serum total bilirubin by pumpkin seed oil indicated decreased cell swelling and obstruction of bile pathway induced by $\mathrm{CCl} 4$, with normal functional status of the liver cells which also restored serum proteins (Seif, 2014 and Morrison et al., 2015).
Concerning to hepatic lipid peroxidation, $\mathrm{CCl} 4$ intoxicated group showed significant increase MDA compared to control rat. These results are in harmony with Palanivel et al., (2008) and Lu et al., (2018).

$\mathrm{CCl} 4$ induced hepatic damage through formation of trichloromethyl free radicals and lipid peroxidation in the liver cells which is the important cause of the liver disease (Weber et al., 2003). Moreover, CCl4 induced oxidative damage in group 3 caused by producing reactive oxygen species and decreasing the biological activities of some antioxidant enzymes, likes SOD and CAT. Our result agrees with Anand et al., (2016) and Lu et al., (2018). Equilibrium between ROS and enzymatic antioxidant enzymes, including SOD, CAT, and GPx are crucial and could be an important mechanism for preventing damage caused by oxidative stress. Elevated oxidative stress has been reported in a variety of chronic liver diseases which arise from increased formation of oxygen free radicals along with deficiencies of antioxidant vitamins and reduced antioxidant enzymes activities (Hamed et al., 2018). In addition, mRNA expression of genes for the antioxidant enzymes, were down-regulated by $\mathrm{CCl} 4$ treatment (Manubolu et al., 2014).

CCl4 protected with pumpkin seed oil showed significant decrease in MDA and significant increase in antioxidant enzymes (SOD and CAT) compared to $\mathrm{CCl} 4$ intoxicated rats. These results agree with Eraslan et al., (2011); Hashemi, (2013) and Seif, (2014). Previous studies reported the antioxidant activity of pumpkin seed oil, as pumpkin rich in essential fatty acids (maintain the fluidity of cell membrane), amino acids, phytosterols, $\beta$ carotenes, phenolics, flavonoids and selenium (Eladawy et al., 2001 \& Procida et al., 2012). Furthermore, pumpkin seed oil rich with vitamin $\mathrm{E}$ which considered as a powerful antioxidant. $\beta$-carotene has been reported to 
have antioxidant and anti-inflammatory activities, it prevents formation of free radicals as nitric oxide and prostaglandin, also it suppressed the inducible nitric oxide synthase (iNOS) and cyclooxygenase (COX-2) expression (Schafer et al., 2002).

Concerning to histopathological alterations our study revealed that $\mathrm{CCl}_{4}$ intoxicated rats have centrilobular coagulative necrosis associated with infiltration of the inflammatory cells (macrophages, lymphocytes, eosinophils), severe hepatic necrosis associated with inflammatory cells infiltration and severe hepatic vacuolation. Congestion of the portal blood vessels with periportal attempts of hepatic proliferation and marked fibroblastic cells proliferation, which come in harmony with Hwang et al., (2007) \& Mahli et al., (2015). However, the animals given pumpkin seed oil at the same time as $\mathrm{CCl}_{4}$ responded by largely avoiding the usual degenerative effects of $\mathrm{CCl}_{4}$, group 4 protected with pumpkin seed oil showed mild focal lesion of coagulative necrosis, marked decrease of hepatic vacuolation, necrosis and inflammatory cells infiltration. These results come in agreement with Abou-zeid et al., (2018) and Fawzy et al., (2018).

Regarding to immunohistochemistry examination of iNOS expression in hepatic tissue, $\mathrm{CCl}_{4}$ induced significant increase of iNOS expression in different parts of the liver tissue, mostly related with with the fibrotic area. These results agree with Anand et al., (2016) and Lu et al., (2018). $\mathrm{CCl}_{4}$ induce free radicals production, these free radicals by the action of NADPH oxidase pathway or intracellular ROS dependent kinase activate the innate immune system and Kupffer cells (Kim et al., 2010). Activated Kupffer cells release the proinflammatory cytokines which involved in liver inflammation. Liver tissue macrophages produce TNF- $\alpha$ which stimulates release of cytokines from macrophages that induces oxidative damage and nitric oxide production. Excess amount of nitric oxide produced by iNOS interact with reactive oxygen species (ROS) to form highly toxic peroxynitrite radicals. These radicals prevent the synthesis of hepatocyte protein leading to hepatocyte metabolic disturbance, that resulting in apoptosis and necrosis of the hepatocytes (Lu et al., 2018). On the other hand, protection with pumpkin seed oil in group 4 prevented the toxic effect induced by $\mathrm{CCl}_{4}$ and revealed mild immunopathological reaction and mild expression of iNOS in hepatic tissue. These results agree with Kandil et al., (2018) who recorded that pumpkin attenuated the apoptosis. Pumpkin seed oil rich in poly unsaturated fatty acids which suppress pro-inflammatory cytokines production and macrophage-mediated cytotoxicity (Shi, 2009). It suppresses TNF- $\alpha$ (Tumor necrosis factor- $\alpha$ ) produced by resident macrophages in $\mathrm{CCl}_{4}$ exposed liver tissue resulting in decrease nitric oxide production and IL-6 (FortisBarrera et al., 2016). From the results of this study, it is concluded that pumpkin seed oil has hepatoprotective and antioxidant effects.

\section{REFERENCES}

Abdo, W., Hirata, A., Sakai, H., El-Sawak, A., Nikami, H. and Yanai, T., (2013). Combined effects of organochlorine pesticides heptachlor and hexachlorobenzene on the promotion stage of hepatocarcinogenesis in rats. Food and Chemical Toxicology 55, 578585 .

Abou-Zeid, S.M., AbuBakr, H.O., Mohamed, M.A. and El-Bahrawy, A., (2018). Ameliorative effect of pumpkin seed oil against emamectin induced toxicity in mice. Biomedicine \& Pharmacotherapy 98, 242-251. 
Adeel, A.; Sohail, A. and Masud, T., (2014). Characterization and antibacterial study of pumpkin seed oil (Cucurbita pepo). Life Sciences Leaflets, pp 49.22774297.

Aghaei, S., Nikzad, H., Taghizadeh, M., Tameh, A., Taherian, A. and Moravveji, A., (2014). Protective effect of Pumpkin seed extract on sperm characteristics, biochemical parameters and epididymal histology in adult male rats treated with Cyclophosphamide. Andrologia 46, 927-935.

Anand, K.V., Anandhi, R., Pakkiyaraj, M. and Geraldine, P., (2011). Protective effect of chrysin on carbon tetrachloride (CC14) - induced tissue injury in male Wistar rats. Toxicology and industrial health 27, 923-933.

Al-Qarawi, A.A., Mousa, H.M., Ali, B.H., Abdel-Rahman, H. and El-Mougy, S.A., (2004). Protective effect of extracts from dates (Phoenix dactylifera L.) on carbon tetrachloride-induced hepatotoxicity in rats. Int $J$ Appl Res Vet Med 2, 176-180.

Al Zuhair, H., El-Fattah, A.A.A .and El-Sayed, M.I., (2000). Pumpkin-seed oil modulates the effect of felodipine and captopril in spontaneously hypertensive rats. Pharmacological Research 41, 555-563.

Bancroft, J.D. and Gamble, M., (2008). Theory and practice of histological techniques . Elsevier health sciences.

Bardaa, S., Halima, N.B., Aloui, F., Mansour, R.B., Jabeur, H., Bouaziz, M. and Sahnoun, Z., (2016). Oil from pumpkin (Cucurbita pepo L.) seeds: evaluation of its functional properties on wound healing in rats. Lipids in health and disease 15, 73 .

Bharti, S.K., Kumar, A., Sharma, N.K., Prakash, O., Jaiswal, S.K., Krishnan, S ,.Gupta, A.K. and Kumar, A., (2013). Tocopherol from seeds of Cucurbita pepo against diabetes: Validation by in vivo experiments supported by computational docking. Journal of the Formosan Medical Association 112, 676-690.

Burtis, C.A., Ashwood, E.R. and Bruns, D.E., (2012). Tietz textbook of clinical chemistry and molecular diagnostics-ebook. Elsevier Health Sciences.

Burtis, C.A. and Bruns, D.E., (2014). Tietz fundamentals of clinical chemistry and molecular diagnostics-e-book. Elsevier Health Sciences.

Chung, M.P.; Yeon, S.C.; Hyun, J.Y.; Chung, W.C. and Young, S.S., (2010). Amelioration of oxidative stress by dandelion extract through CYP2E1 suppression against acute liver injury induced by carbon tetrachloride in sprague-dawley rats. Phytother. Res. 24, 9:1347- 1353.

Davoudi, S.M., Eshagian, M. and EdalatiNasab, M., (2013). Overview of Hepatic Disease in Large Animals. Society of Education, India 4, 12-20.

El-Adawy, T.A. and Taha, K.M., (2001). Characteristics and composition of watermelon, pumpkin, and paprika seed oils and flours. Journal of agricultural and food chemistry 49, 1253-1259.

Eraslan, G., Kanbur, M., Aslan, Ö. and Karabacak, M., (2013). The antioxidant effects of pumpkin seed oil on subacute aflatoxin poisoning in mice. Environmental toxicology 28, 681-688. 
Fahim, A.T., Abd-El Fattah, A.A., Agha, A.M. and Gad, M.Z., (1995). Effect of pumpkin-seed oil on the level of free radical scavengers induced during adjuvant-arthritis in rats . Pharmacological Research 31, 73-79.

Fadhel, Z.A. and Amran, S., (2002). Effects of black tea extract on carbon tetrachloride-induced lipid peroxidation in liver, kidneys, and testes of rats. Phytotherapy Research 16 ,28-32.

Fawzy, E.I., E1 Makawy, A.I., El-Bamby, M.M. and Elhamalawy, H.O., (2018). Improved effect of pumpkin seed oil against the bisphenol-A adverse effects in male mice. Toxicology reports 5, 857863.

Fortis-Barrera, Á. García-Macedo, R.; Almanza-Perez, J.; Blancas-Flores, G.; Zamilpa-Alvarez, A.; Flores-Sáenz, J.; Cruz, M., Román-Ramos, R. and Alarcón-Aguilar, F., (2016). Cucurbita ficifolia (Cucurbitaceae) modulates inflammatory cytokines and IFN- $\gamma$ in obese mice. Canadian journal of physiology and pharmacology 95, 170177.

George, S. and Nazni, P., (2012). Antidepressive activity of processed pumpkin (Cucurbita maxima) seeds on rats. Int. J. Pharm. Med. \& Bio. Sc 1, 225-231.

Gossell-Williams, M., Lyttle, K., Clarke, T., Gardner, M. and Simon, O., (2008). Supplementation with pumpkin seed oil improves plasma lipid profile and cardiovascular outcomes of female nonovariectomized and ovariectomized Sprague-Dawley rats. Phytotherapy Research 22, 873-877.
Hashemi, J.M., (2013). Pumpkin seed oil and vitamin $\mathrm{E}$ improve reproductive function of male rats inflicted by testicular injury. World Applied Sciences Journal 23, 1351-1359.

Hamed, H.; ElFeki, A. and Gargouri, A., (2018). Toxic Effects of Acute Exposure of Mice to Carbon Tetrachloride and Possible Preventive Role of Camel Milk.

Henry, R., Cannon, D. and Win, J., (1974). Method of protein determination in plasma. Clinical Chemistry 20, 13621363.

Hwang, Y.P., Choi, C.Y., Chung, Y.C., Jeon, S.S. and Jeong, H.G., (2007). Protective effects of puerarin on carbon tetrachloride-induced hepatotoxicity. Archives of pharmacal research 30 , 1309.

Kandeil, M.A.M., Kamel Mohamed Abd Alla Hassanin, E.T.M., Safwat, G.M. and Mohamed, D.S., (2018). Pumpkin and Vitamin E as Potent Modulators of Apoptosis in Gentamicin-induced Rat Nephrotoxicity. Asian Journal of Biochemistry 13, 1-8.

Kim, H.-Y., Park, J., Lee, K.-H., Lee, D.-U., Kwak, J.-H., Kim, Y.S. and Lee, S.-M., (2011). Ferulic acid protects against carbon tetrachloride-induced liver injury in mice. Toxicology 282, 104-111.

Kowalska, M., Brandt, M. and Puett, D., (1990). Inhibition of cytochrome P-450 aromatase activity by plant extracts. Planta medica 56, 675-675.

Lum, H. and Roebuck, K.A., (2001). Oxidant stress and endothelial cell dysfunction. American Journal of Physiology-Cell Physiology 280, C719-C741. 
Lu, Y.-H., Tian, C.-R., Gao, C.-Y., Wang, W.-J., Yang, W.-Y., Kong, X., Chen, Y.-X. and Liu, Z.-Z., (2018). Protective effect of free phenolics from Lycopus lucidus Turcz. root on carbon tetrachlorideinduced liver injury in vivo and in vitro . Food \& nutrition research 62 .

Makni, M., Fetoui, H., Gargouri, N., Garoui, E.M., Jaber, H., Makni, J., Boudawara, $\mathrm{T}$.and Zeghal, N., (2008). Hypolipidemic and hepatoprotective effects of flax and pumpkin seed mixture rich in $\omega-3$ and $\omega-6$ fatty acids in hypercholesterolemic rats. Food and Chemical Toxicology 46, 3714-3720.

Mahli, A., Koch, A., Czech, B., Peterburs, P., Lechner, A., Haunschild, J., Müller, M. and Hellerbrand, C., (2015). Hepatoprotective effect of oral application of a silymarin extract in carbon tetrachloride-induced hepatotoxicity in rats. Clinical Phytoscience 1, 5.

Manubolu, M.; Goodla, L.; Ravilla, S.; Thanasekaran, J.; Dutta, P.; Malmlöf, K. and Obulum, V.R., (2014). Protective effect of Actiniopteris radiata (Sw.) Link. against $\mathrm{CCl} 4$ induced oxidative stress in albino rats. Journal of Ethnopharmacology153, 744-752.

Medjakovic, S., Hobiger, S., ArdjomandWoelkart, K., Bucar, F. and Jungbauer, A., (2016). Pumpkin seed extract: Cell growth inhibition of hyperplastic and cancer cells, independent of steroid hormone receptors. Fitoterapia 110, $150-156$.

Morrison, M.C., Mulder ,P., Stavro, P.M., Suárez, M., Arola-Arnal, A., Van Duyvenvoorde, W., Kooistra, T., Wielinga, P.Y. and Kleemann, R., (2015). Replacement of dietary saturated fat by PUFA-rich pumpkin seed oil attenuates non-alcoholic fatty liver disease and atherosclerosis development, with additional health effects of virgin over refined oil. PloS one $10, \mathrm{e} 0139196$.

Mohamed, R.A., Ramadan, R.S. and Ahmed, L.A., (2009). Effect of substituting pumpkin seed protein isolate for casein on serum liver enzymes, lipid profile and antioxidant enzymes in CCl4intoxicated rats. Advances in Biological Research 3, 09-15.

Murkovic, M., Hillebrand, A., Winkler, J. and Pfannhauser, W., (1996). Variability of vitamin $\mathrm{E}$ content in pumpkin seeds (Cucurbita pepo L). Zeitschrift für Lebensmittel-Untersuchung und Forschung 202, 275-278.

Ojiako, O.A. and Nwanjo, H.U., (2006). Is veronicas amygdalina hepatotoxic or hepatoprotective? Response from toxicity and biochemical studies. African journal of Biotechnology 5(8): 1648-1651.

Olivera,M.L.M., Nunes-Pinheiro, D.C.S., and Bezerra, B.M.O., (2013). “Topical Antiinflammatory Potential of Pumpkin (Cucurbita pepo L.) Seed Oil on Acute and Chronic Skin Inflammation in Mice," Acta Scientiae Veterinariae, vol. 41, p. 1168.

Osadebe, P.O., Okoye, F.B., Uzor, P.F., Nnamani, N.R., Adiele, I.E. and Obiano, N.C., (2012). Phytochemical analysis, hepatoprotective and antioxidant activity of Alchornea cordifolia methanol leaf extract on carbon tetrachloride-induced hepatic damage in rats. Asian Pacific journal of tropical medicine 5, 289-293. 
Palanivel, M., Rajkapoor, B., Kumar, R., Einstein, J., Kumar, E., Kumar, M., Kavitha, K., Kumar, M. and Jayakar, B., (2008) .(Hepatoprotective and antioxidant effect of Pisonia aculeata L. against CCl4-induced hepatic damage in rats. Scientia pharmaceutica 76, $203-$ 216.

Procida, G., Stancher, B., Cateni, F. and Zacchigna, M., (2012). Chemical composition and functional characterization of commercial pumpkin seed oil. ChimAlSi 2012, IX Italian Congress of Food," Food, Functional Foods and Nutraceuticals". Faculty of Food and Agriculture, United Arab Emirates University, pp. 63-63.

Reinhold, B., (1992). Evaluation of the chemical properties of plant extracts in Africa. J Egypt Soc Horti 16, 497-498.

Saba, A., Oyagbemi, A. and Azeez, O., (2010). Amelioration of carbon tetrachlorideinduced hepatotoxicity and haemotoxicity by aqueous leaf extract of Cnidoscolus aconitifolius in rats. Nigerian Journal of Physiological Sciences 25, 139-147.

Schafer, F.Q., Wang, H.P., Kelley, E.E., Cueno, K.L., Martin, S.M. and Buettner, G.R., (2002). Comparing $\beta$-carotene, vitamin $E$ and nitric oxide as membrane antioxidants. Biological chemistry 383 , 671-681.

Srivastava, A. and Shivanandappa, T., (2010). Hepatoprotective effect of the root extract of Decalepis hamiltonii against carbon tetrachloride-induced oxidative stress in rats. Food Chemistry 118, 411417.
Stanković, M., Topuzović, M., Marković, A., Pavlović, D., Solujić, S., Nićiforović, N. and Mihailović, V., (2010). Antioxidant Activity, Phenol and Flavonoid Contents of Different Teucrium Chamaedrys L. Exstracts. Biotechnology \& Biotechnological Equipment 24, 82-86.

Seif, H.S.A., (2014). Ameliorative effect of pumpkin oil (Cucurbita pepo L.) against alcohol-induced hepatotoxicity and oxidative stress in albino rats. Beni-Suef University Journal of Basic and Applied Sciences 3, 178-185.

Sengottuvelu, S., Srinivasan, D., Duraisami, R., Nandhakumar, J., Vasudevan, M. and Sivakumar, T. (2008). Hepatoprotective activity of Trianthema decandra on carbon tetrachloride-induced hepatotoxicity in rats. International Journal of Green Pharmacy (IJGP) 2.

Shi, Y. and Pestka, J.J., (2009). Mechanisms for suppression of interleukin-6 expression in peritoneal macrophages from docosahexaenoic acid-fed mice. The Journal of nutritional biochemistry 20, 358-368.

Sheweita, S., El-Gabar, M.A. and Bastawy, M., (2001). Carbon tetrachloride-induced changes in the activity of phase II drugmetabolizing enzyme in the liver of male rats: role of antioxidants. Toxicology 165, 217-224.

Spring, P., Wenk, C., Dawson, K. and Newman, K., (2000). The effects of dietary mannaoligosaccharides on cecal parameters and the concentrations of enteric bacteria in the ceca of salmonella-challenged broiler chicks. Poultry science 79, 205-211. 
Tochukwu, N., Kenneth, A., Somadina, O., Chukwuebuka, N. and Chigozie, I., (2018). Curative and Protective Efficacy of Cassio occidentalis Ethanolic Leaf Extract on Carbon Tetrachloride Induced Liver Damage of Female Albino Wistar Rats. EC Clinical \& Experimental Anatomy 1.2 (2018): 48-61.

Vekemans, K. and Braet, F. (2005). Structural and functional aspects of the liver and liver sinusoidal cells in relation to colon carcinoma metastasis. World journal of gastroenterology, 11(33), 5095-5102. doi:10.3748/wjg.v11.i33.5095.
Weber, L.W., Boll, M. and Stampfl, A., (2003). Hepatotoxicity and mechanism of action of haloalkanes: carbon tetrachloride as a toxicological model. Critical reviews in toxicology 33, 105136.

Young, D.S., (1995). Effects of drugs on clinical laboratory tests. The American Association for Clinical Chemistry. 